\title{
Association of Maternal and Child Health Center (Posyandu) Availability with Child Weight Status in Indonesia: A National Study
}

\author{
Helen Andriani ${ }^{1, \dagger}$, Chu-Yung Liao ${ }^{2, \dagger}$ and Hsien-Wen Kuo ${ }^{1,3,4, *}$ \\ 1 International Health Program, Institute of Public Health, National Yang Ming University, Taipei 112, Taiwan; \\ helen_a9@yahoo.com \\ 2 Department of Early Childhood Educare, College of Health, Chung Chou University of Science and \\ Technology, Changhua 510, Taiwan; cyliao@dragon.ccut.edu.tw \\ 3 Institute of Environmental and Occupational Health Sciences, National Yang-Ming University, \\ Taipei 112, Taiwan \\ 4 School of Public Health, National Defense Medical Center, Taipei 112, Taiwan \\ * Correspondence: hwkuo@ym.edu.tw; Tel.: +886-2-2827-2294 \\ + These authors contributed equally to this work.
}

Academic Editor: María M. Morales Suárez-Varela

Received: 27 December 2015; Accepted: 29 February 2016; Published: 7 March 2016

\begin{abstract}
Little is known about the childhood obesity prevention and treatment practices of Maternal and Child Health services (Posyandu) in Indonesia or in other countries. The present study aims to assess the association of the availability of Posyandu with overweight and obesity in children of different household wealth levels. This was a secondary analysis of data collected in the 2013 Riskesdas (or Basic Health Research) survey, a cross-sectional study, representative population-based data. Height and weight, the availability of Posyandu, and basic characteristics of the study population were collected from parents with children aged 0 to 5 years $(n=63,237)$. Non-availability of Posyandu significantly raised the odds of being obese (OR $=1.13,95 \% \mathrm{CI}: 1.06-1.21)$ and did not show a significant relationship in the odds for overweight (OR $=0.99,95 \%$ CI: 0.93-1.07). This relationship persisted after a full adjustment $(\mathrm{OR}=1.16,95 \% \mathrm{CI}$ : $1.07-1.25$ and $\mathrm{OR}=1.04,95 \%$ CI: $0.96-1.13$, respectively). There was effect modification by household wealth, which was stronger for obese children. The availability of Posyandu has a protective association with childhood obesity in Indonesia. Posyandu services are well placed to play an important role in obesity prevention and treatment in early life.
\end{abstract}

Keywords: maternal; child; community-participation; primary health care; obesity; Indonesia

\section{Introduction}

For quite some time, overweight and obesity were considered primarily problems of developed countries. However, with increasing incomes, urbanization, and changing lifestyles, the developing countries are facing the same issues [1]. Globally, the number of overweight children under the age of five in 2010 was estimated to be over 42 million. Close to 35 million of these are living in developing countries [2]. As a developing country, Indonesia is also facing a substantial increase in the numbers of overweight (including obese) children. While Indonesian government continues efforts to reduce hunger, that focus neglects the growing rate of overweight. In 1993, overweight prevalence among children under-five was 4.6\%. This figure has increased very dramatically in 2007 and 2010, with the estimated prevalence of overweight was equal to $12.2 \%$ and $14.2 \%$, respectively [3,4]. Overweight and obesity in children are associated with increased risk of hypertension, heart disease, diabetes mellitus, and sleep disturbances in adulthood $[5,6]$. 
The Indonesian government has focused on improving Maternal Child Health $(\mathrm{MCH})$, by extending health services to urban and rural communities through the organization of volunteer-staffed Integrated Health Service Post (Posyandu), following the international call of the Declaration of Alma-Ata (Kazakhstan) about Primary Health Care in 1978, convened by WHO and the United Nations Children's Fund (UNICEF) [7]. Posyandu activity rapidly flourished throughout the nation: a jump up in the number of Posyandu from only 25,000 in 1985 to 244,382 in 1990. After that, the number of Posyandu in the country did not increase further, and may have even decreased [8]. Implementation of Posyandu requires intersectoral collaboration between the Department of Home Affairs and the Department of Health at the sub-district level [9].

The volunteers, who are called village health workers (Kader), have to be recruited and trained to recognize basic health care issues, such as nutrition, maternal and child health, family planning, immunization, and prevention of diarrhea. As part of the community, Kader would be much easier to deliver health programs because they are closer to the community compare to the public health officials. Kader usually are married women and members of the Family Welfare Movement. The Kader receive a week of training to carry out the Posyandu activities and a financial incentive for their work [10] Recruiting Kader, providing suitable venues and preparing for each monthly session are the shared responsibility of the local village community development committee, the Family Welfare Movement, and the village head. Programming and scheduling of sessions are coordinated by the health facility staff and the sub-district local government head, and health facility staff provides on-the-job training and supervise the Kader [11,12]. Historically in Indonesia, the presence of health volunteers and an active women's organization at the village level have been credited with lowering fertility and improving child survival [13].

One Posyandu serves to approximately 50 children under 5 years of age, or its services are adjusted to the capability of the Kader and to local conditions, such as geographical conditions, distance between dwellings, number of households, etc. The Posyandu program is conducted every month in every village level. The operational of Posyandu is supported by medical doctor or midwife from sub district clinic and Kader or village volunteers. In terms of childhood obesity prevention, the Kader frequently undertake growth monitoring through weighing. In this way, the children's weight gain can be monitored from one month to another. Therefore the children's weight gain can be monitored from one month to another. In terms of childhood obesity treatment, in case of an increased trend of body weight or above the red line, the Kader are expected to give nutritional education or advice, make referrals to Public Health Centers, and address food supplements or feeding practices. Posyandu has been considered the most essential mechanism to enhance the nutrition improvement and toddler and baby mortality rate [14].

However, little is known about the childhood obesity prevention and treatment practices of Posyandu in Indonesia or in other countries. The limited number of existing studies to date have been studies exploring how participation of children in the Posyandu nutrition program improve children nutritional status [15] or a small scale qualitative study exploring the differences among the three Posyand $u$ at different villages, how mother or father understood the growth chart, and the implications of gaining weight or not gaining [16]. Health status and service access differs substantially in particular between the rich and the poor [17]. The poor compared to the rich, have poorer health outcomes and is one of influencing factors contributing to health inequalities $[18,19]$. The rich-poor gap in child nutritional status, measured through the proportion of underweight children have been suggested including household expenditure [17]. We are unaware of any previous studies that comprehensively describe how the availability of Posyandu recently associate with overweight and obesity in children and whether such associations would change in different household wealth.

Therefore the aims of this paper were to: (1) examine the association of the availability of Posyandu, travel time to Posyandu, and travel cost to Posyandu with overweight and obesity in children, and (2) explore such associations in different household wealth. 


\section{Materials and Methods}

\subsection{Data Sources}

This study involved a secondary analysis from the 2013 Riskesdas (or Basic Health Research) survey, a cross-sectional, nationally representative survey of the Indonesian population. The 2013 Riskesdas is the third survey conducted in Indonesia under the National Institute of Health Research and Development(NIHRD), Ministry of Health Republic of Indonesia. A two-stage, stratified cluster sampling approach was used for the selection of the survey sample. Two sampling frames were used for each stage. At the first stage, all 30,000 Primary Sampling Units included in the master list of census blocks were selected according to probability proportional to size (PPS) with the number of households Population Census in 2010. Two census blocks were selected according to PPS, while the size was the number of households in each districts based on the list of the 2010 Population Census. At the second stage, twenty five census buildings in each census blocks were selected using systematic random sampling. Finally one household in each census building was selected using random sampling. Sampling was conducted among a national sample of 150 sub census blocks in all 33 provinces with the total 497 districts / cities in Indonesia. A complete interview was obtained for 294,959 households from targeted 300,000 households (98.3 percent). The eligible children included all biological, step, or adopted children of the household head and spouse, as well as any children fostered to any adult in the household.

\subsection{Measurement}

The anthropometric measurements (height and weight) and information regarding the availability of Posyandu and basic characteristics of the study population were collected from parents with children aged 0 to 5 years in 2013. The trained interviewers (usually nurses) collected the height and weight measurements following accepted international standards. Standing height measures (for children over age two) and recumbent lengths (for younger children) were taken using a Multifunction brand (Brooklyn, NY, USA) stadiometer; measures of weight were taken using a Fesco (Brooklyn, NY, USA) digital weight scale, calibrated daily, including calibration across nurses who measure the height and weight. Both of these measuring instruments have been used in survey work in other countries and are suitable for field work given their portability, durability, and accuracy. Children who were too young or not able to stand on their own were held by a parent and weighted (after the scale had been adjusted to zero with just the parent alone on the scale).

Height and weight were used to calculate Body Mass Index (BMI). BMI z-scores were determined for each child based on the 2006 WHO Child Growth Standards for children under five years old, age and sex specific. Underweight was defined as BMI z-score $\leqslant-2 \mathrm{SD}$. Healthy weight was defined as $-2 \mathrm{SD}<\mathrm{BMI} z$-score $<2 \mathrm{SD}$. Overweight was defined as $2 \mathrm{SD} \leqslant \mathrm{BMI} z$-score $<3 \mathrm{SD}$. Obese was defined as BMI $z$-score $\geqslant 3$ SD [20,21].

There were 82,666 children under five years old in 2013. Of those, a total of 11,009 (13.3\%) children with missing data on height and weight had to be eliminated from the sample. Children classified as underweight (8420 children or $10.2 \%$ ) according to WHO were also excluded, leaving healthy weight, overweight, and obese status for the analysis. The final sample included 63,237 children. For the availability of Posyandu, data were collected through proxy interviews (usually a mother), the question was "Do you know if there are health facilites available nearby, including Posyandu? (Available/not available)." Nearby means at least one health facility, including Posyandu was located in the same or different village where the household was located. If the respondent answered "available", then the next questions such as "How long does it take to visit the nearest health facilities, including Posyandu?" and "How much does it cost to visit the nearest health facilities, including Posyandu?" were asked. Travel time to Posyand $u$ was categorized into: $\leqslant 15 \mathrm{~min},>15 \mathrm{~min}$, and not available. Travel cost to Posyandu (in Rupiah) was categorized into: $<5000$ Rupiah, $\geqslant 5,000$ Rupiah, and not available. The 
outcome variable was child weight status, measured as categorical (healthy weight, overweight, and obese) variable.

\subsection{Potential Covariates and Effect Measure Modifier}

We considered the following as covariates for child weight status: child's gender (boy and girl), breastfeeding (no and yes), father's education (none, elementary, junior high school, senior high school, and post-graduate), parental BMI (both parents $<25 \mathrm{~kg} / \mathrm{m}^{2}$, only mother $\geqslant 25 \mathrm{~kg} / \mathrm{m}^{2}$, only father $\geqslant 25 \mathrm{~kg} / \mathrm{m}^{2}$, and both parents $\geqslant 25 \mathrm{~kg} / \mathrm{m}^{2}$ ), household wealth (poorer and wealthier), and residence (urban and rural). Poorer represents the lowest fifth of the data. Wealthier represents the second fifth to the highest fifth of the data. These self-reported covariates, collected through interviews, allowed for the control of variables that might influence child weight status. Household wealth was an effect modifier of interest.

\subsection{Statistical Analyses}

We performed all statistical analyses using SPSS 20.0 for Windows (IBM, Armonk, NY, USA). The variables in the study were evaluated using descriptive statistics including chi-square as appropriate. A multinomial logistic regression model, with healthy weight as a reference category controlled for covariates estimated the odds ratios (ORs) and 95\% confidence intervals of overweight and obese. Data has been analyzed by adjusting the sampling weight for survey analysis. We set the statistical threshold for significance at 0.05 .

\subsection{Ethical Considerations}

The survey and its procedures were properly reviewed and approved by IRBs (LB.02.01/5.2/KE.006/2013) in Indonesia, at the Health Research Ethics Committee-University of Indonesia, Hasanuddin University, the University of Airlangga, and The National Institute of Health Research and Development (NIHRD), Ministry of Health Republic of Indonesia.

\section{Results}

\subsection{Univariate Analysis for Children Weight Status and the Availability of Posyandu}

Table 1 showed the availability of Posyandu, travel time to Posyandu, travel cost to Posyandu, and basic characteristics of the study population across categories of children weight status. We found the percentage of healthy weight, overweight, and obese children to be $76.4 \%, 6.0 \%$, and $5.9 \%$, respectively. Among the overweight or obese children, majority of them lived in the areas where a Posyandu existed, spent $\leqslant 15$ min and $<5000$ Rupiah on travels, were boys, were breast-fed, had higher educated father, had healthy weight parents, or were wealthier.

\subsection{The Association of the Availability of Posyandu, Travel Time to Posyandu, and Travel Cost to Posyandu} with Overweight and Obese in Children

The association of the availability of Posyandu with child weight status was estimated using multinomial logistic regression model (Table 2). Non-availability of Posyandu significantly raised the odds of being obese (OR $=1.13,95 \% \mathrm{CI}: 1.06-1.21)$. This finding was confirmed by more objective measurement such as travel time to Posyandu (OR $=1.14,95 \%$ CI: 1.06-1.22) and travel cost to Posyandu $(\mathrm{OR}=1.21,95 \% \mathrm{CI}: 1.13-1.30)$. High travel cost ( $\geqslant 5000$ Rupiah) to Posyandu significantly raised the odds of being overweight ( $\mathrm{OR}=1.15,95 \% \mathrm{CI}: 1.06-1.26)$ and obese ( $\mathrm{OR}=1.33,95 \%$ CI: $1.22-1.44)$. After adjusting for the covariates, compared to the availability of Posyandu, non-availability of Posyandu showed a significant 1.16-fold increased odds of obesity (adjusted OR $=1.16,95 \%$ CI: 1.07-1.25). This was confirmed by travel time to Posyand $u$ (adjusted OR $=1.18,95 \%$ CI: 1.09-1.27) and travel cost to Posyandu (adjusted OR $=1.24,95 \%$ CI: 1.14-1.35). Compared to short travel time ( $\leqslant 15 \mathrm{~min}$ ) to Posyandu, long travel time ( $>15 \mathrm{~min}$ ) to Posyandu showed a significant 1.24-fold increased odds 
of obesity (adjusted OR $=1.24,95 \%$ CI: 1.06-1.45). Compared to low travel cost ( $<5000$ Rupiah) to Posyandu, high travel cost ( $\geqslant 5000$ Rupiah) to Posyandu showed a significant 1.13-fold increased odds of overweight (adjusted OR $=1.13,95 \%$ CI: 1.02-1.24) and 1.32-fold increased odds of obesity (adjusted $\mathrm{OR}=1.32,95 \%$ CI: $1.20-1.46)$.

Table 1. The availability of Posyandu, travel time to Posyandu, travel cost to Posyandu, and basic characteristics of the study population across categories of children weight status.

\begin{tabular}{|c|c|c|c|c|c|}
\hline \multirow[b]{2}{*}{ Variables } & \multirow[b]{2}{*}{ Categories } & \multirow[b]{2}{*}{ Total $(N=63,237)$} & \multicolumn{3}{|c|}{ Children Weight Status } \\
\hline & & & $\begin{array}{c}\text { Healthy } \\
\text { Weight } n(\%) \\
(N=54,755)\end{array}$ & $\begin{array}{l}\text { Overweight } n \\
(\%)(N=4271)\end{array}$ & $\begin{array}{c}\text { Obese } n(\%) \\
(N=4211)\end{array}$ \\
\hline \multirow{2}{*}{$\begin{array}{c}\text { The Availability } \\
\text { of Posyandu }\end{array}$} & Available & $44,597(70.5)$ & $38,709(70.7)$ & $3020(70.7)$ & $2868(68.1)$ \\
\hline & Not Available & $18,640(29.5)$ & $16,046(29.3)$ & $1251(29.3)$ & $1343(31.9)$ \\
\hline \multirow{3}{*}{$\begin{array}{l}\text { Travel Time to } \\
\text { Posyandu }\end{array}$} & $\leqslant 15 \mathrm{~min}$ & $41,204(65.2)$ & $35,785(65.4)$ & $2787(65.3)$ & $2632(62.5)$ \\
\hline & $>15 \mathrm{~min}$ & $3393(5.4)$ & $2924(5.3)$ & $233(5.5)$ & $236(5.6)$ \\
\hline & Not Available & $18,640(29.5)$ & $16,046(29.3)$ & $1251(29.3)$ & $1343(31.9)$ \\
\hline \multirow{3}{*}{$\begin{array}{l}\text { Travel Cost to } \\
\text { Posyandu }\end{array}$} & $<5000$ Rupiah & $34,659(54.8)$ & $30,278(55.3)$ & $2286(53.5)$ & $2095(49.8)$ \\
\hline & $\geqslant 5000$ Rupiah & 9938 (15.7) & $8431(15.4)$ & $734(17.2)$ & $773(18.4)$ \\
\hline & Not Available & $18,640(29.5)$ & $16,046(29.3)$ & $1251(29.3)$ & $1343(31.9)$ \\
\hline \multirow{2}{*}{ Child's Gender } & Boys & $31,640(50.0)$ & $27,243(49.8)$ & $2221(52.0)$ & $2176(51.7)$ \\
\hline & Girls & $31,597(50.0)$ & $27,512(50.2)$ & $2050(48.0)$ & $2035(48.3)$ \\
\hline \multirow{2}{*}{ Breastfeeding } & No & $3580(5.7)$ & $1408(2.6)$ & $1226(28.7)$ & $946(22.5)$ \\
\hline & Yes & $59,657(94.3)$ & $53,347(97.4)$ & 3045 (71.3) & 3265 (77.5) \\
\hline \multirow{5}{*}{$\begin{array}{l}\text { Father's } \\
\text { Education }\end{array}$} & None & 6049 (11.6) & $5290(11.8)$ & $354(9.9)$ & $405(11.3)$ \\
\hline & Elementary & $12,669(24.3)$ & $10,953(24.3)$ & $888(24.7)$ & $828(23.0)$ \\
\hline & Junior High & $10,552(20.2)$ & 9069 (20.1) & 705 (19.6) & 778 (21.6) \\
\hline & Senior High & $17,368(33.3)$ & $14,989(33.3)$ & $1218(33.9)$ & $1161(32.3)$ \\
\hline & Post-graduate & 5553 (10.6) & 4707 (10.5) & $423(11.8)$ & $423(11.8)$ \\
\hline \multirow{4}{*}{$\begin{array}{l}\text { Parental BMI } \\
\quad\left(\mathrm{kg} / \mathrm{m}^{2}\right)\end{array}$} & Both parents $<25$ & $26,326(55.9)$ & $22,723(58.8)$ & 1751 (41.2) & $1852(44.0)$ \\
\hline & Only mother $\geqslant 25$ & $9821(20.8)$ & 8039 (20.8) & $1158(27.2)$ & $624(14.8)$ \\
\hline & Only father $\geqslant 25$ & $5966(12.7)$ & 4752 (12.3) & 815 (19.2) & $399(9.5)$ \\
\hline & Both parents $\geqslant 25$ & 5009 (10.6) & $3146(8.1)$ & $530(12.5)$ & $1333(31.7)$ \\
\hline \multirow{2}{*}{$\begin{array}{l}\text { Household } \\
\text { Wealth }\end{array}$} & Poorer & $12,620(20.0)$ & $11,050(20.2)$ & $781(18.3)$ & 789 (18.7) \\
\hline & Wealthier & $50,617(80.0)$ & $43,705(79.8)$ & $3490(81.7)$ & $3422(81.3)$ \\
\hline \multirow{2}{*}{ Residence } & Urban & $28,809(45.6)$ & $24,903(45.5)$ & $1981(46.4)$ & 1925 (45.7) \\
\hline & Rural & $34,428(54.4)$ & $29,825(54.5)$ & $2290(53.6)$ & $2286(54.3)$ \\
\hline
\end{tabular}

3.3. The Association of the Availability of Posyandu, Travel Time to Posyandu, and Travel Cost to Posyandu with Overweight and Obese in Children in Different Household Wealth

From the stratified analyses in Table 3, compared to children who lived in the areas where a Posyandu existed, the odds ratio of being obese was statistically significantly higher among children from wealthier families (OR $=1.14,95 \%$ CI: 1.06-1.24) who lived in the areas where a Posyandu did not exist. After adjusting for the covariates using multinomial logistic regression model, children from wealthier families (adjusted OR $=1.17,95 \%$ CI: 1.07-1.27) who lived in the areas where a Posyandu did not exist were associated with higher odds of being obese. This was confirmed by travel time to Posyand $u$ (adjusted OR $=1.17,95 \%$ CI: $1.08-1.28$ ) and travel cost to Posyandu (adjusted OR $=1.27,95 \%$ CI: 1.16-1.39). 
Table 2. Odds ratio and adjusted odds ratio (95\% CI) using multinomial logistic regression model for overweight or obese compared to healthy weight according to the availability of Posyandu, travel time to Posyandu, and travel cost to Posyandu.

\begin{tabular}{|c|c|c|c|c|c|}
\hline \multirow{2}{*}{ Variables } & \multirow{2}{*}{ Categories } & \multicolumn{2}{|c|}{ Overweight $^{+}$} & \multicolumn{2}{|c|}{ Obese $^{+}$} \\
\hline & & cOR $(95 \%$ CI $)$ & $\mathrm{aOR}^{\mathrm{a}}(95 \% \mathrm{CI})$ & cOR $(95 \% \mathrm{CI})$ & $\mathrm{aOR}^{\mathrm{a}}(95 \% \mathrm{CI})$ \\
\hline \multirow{2}{*}{$\begin{array}{c}\text { The Availability } \\
\text { of Posyandu }\end{array}$} & Available & 1 & 1 & 1 & 1 \\
\hline & Not Available & $0.99(0.93-1.07)$ & $1.04(0.96-1.13)$ & $1.13^{* *}(1.06-1.21)$ & $1.16^{* *}(1.07-1.25)$ \\
\hline \multirow{3}{*}{$\begin{array}{l}\text { Travel Time } \\
\text { to Posyandu }\end{array}$} & $\leqslant 15 \min$ & 1 & 1 & 1 & 1 \\
\hline & $>15$ min & $1.02(0.89-1.18)$ & $1.16(0.99-1.36)$ & $1.10(0.96-1.26)$ & $1.24^{* *}(1.06-1.45)$ \\
\hline & Not Available & $1.01(0.93-1.07)$ & $1.06(0.98-1.15)$ & $1.14^{* *}(1.06-1.22)$ & $1.18^{* *}(1.09-1.27)$ \\
\hline \multirow{3}{*}{$\begin{array}{l}\text { Travel Cost } \\
\text { to Posyandu }\end{array}$} & $<5000$ Rupiah & 1 & 1 & 1 & 1 \\
\hline & $\geqslant 5000$ Rupiah & $1.15^{* *}(1.06-1.26)$ & $1.13 *(1.02-1.24)$ & $1.33^{* *}(1.22-1.44)$ & $1.32 * *(1.20-1.46)$ \\
\hline & Not Available & $1.03(0.96-1.11)$ & 1.07 (0.99-1.17) & $1.21^{* *}(1.13-1.30)$ & $1.24^{* *}(1.14-1.35)$ \\
\hline
\end{tabular}

Notes: $\mathrm{cOR}=$ Crude Odds Ratio; $\mathrm{aOR}=$ Adjusted Odds Ratio; $\mathrm{CI}=$ Confidence Interval; ${ }^{\dagger}$ Healthy weight is the reference category; ${ }^{*} p<0.05 ;{ }^{* *} p<0.01$; $^{\text {a }}$ adjusted for breastfeeding, father's education, parental BMI, and household wealth.

Table 3. Odds ratio and adjusted odds ratio (95\% CI) using multinomial logistic regression model for overweight or obese compared to healthy weight according to the availability of Posyandu, travel time to Posyandu, and travel cost to Posyandu, stratified by household wealth

\begin{tabular}{|c|c|c|c|c|c|}
\hline \multirow{3}{*}{ Variables } & \multirow{3}{*}{ Categories } & \multicolumn{4}{|c|}{ Poorer $(N=12,620)$} \\
\hline & & \multicolumn{2}{|c|}{ Overweight $^{\dagger}$} & \multicolumn{2}{|c|}{ Obese $^{+}$} \\
\hline & & cOR & $\mathrm{aOR}^{\mathrm{a}}(95 \% \mathrm{CI})$ & cOR & $\mathrm{aOR}^{\mathrm{a}}(95 \% \mathrm{CI})$ \\
\hline \multirow{2}{*}{$\begin{array}{c}\text { The Availability } \\
\text { of Posyandu }\end{array}$} & Available & 1 & 1 & 1 & 1 \\
\hline & Not Available & $1.01(0.87-1.17)$ & $0.97(0.81-1.15)$ & $1.14(0.98-1.32)$ & $1.08(0.91-1.27)$ \\
\hline \multirow{3}{*}{$\begin{array}{c}\text { Travel Time to } \\
\text { Posyandu }\end{array}$} & $\leqslant 15 \mathrm{~min}$ & 1 & 1 & 1 & 1 \\
\hline & $>15 \min$ & $1.28 *(1.02-1.60)$ & $1.46^{* *}(1.12-1.90)$ & $1.30 *(1.04-1.64)$ & $1.50 * *(1.16-1.93)$ \\
\hline & Not Available & $1.06(0.91-1.24)$ & $1.05(0.87-1.26)$ & $1.20 *(1.03-1.41)$ & $1.17(0.98-1.40)$ \\
\hline \multirow{3}{*}{$\begin{array}{l}\text { Travel Cost to } \\
\text { Posyandu }\end{array}$} & $<5000$ Rupiah & 1 & 1 & 1 & 1 \\
\hline & $\geqslant 5000$ Rupiah & $0.99(0.78-1.26)$ & $0.82(0.62-1.08)$ & $1.33 *(1.06-1.66)$ & $1.19(0.93-1.53)$ \\
\hline & Not Available & $1.01(0.86-1.17)$ & $0.93(0.77-1.12)$ & $1.21 *(1.04-1.41)$ & $1.12(0.94-1.34)$ \\
\hline \multirow{3}{*}{ Variables } & \multirow{3}{*}{ Categories } & \multicolumn{4}{|c|}{ Wealthier $(N=50,617)$} \\
\hline & & \multicolumn{2}{|c|}{ Overweight $^{\dagger}$} & \multicolumn{2}{|c|}{ Obese $^{\dagger}$} \\
\hline & & cOR & $\mathrm{aOR}^{\mathrm{a}}(95 \% \mathrm{CI})$ & cOR & $\mathrm{aOR}^{\mathrm{a}}(95 \% \mathrm{CI})$ \\
\hline \multirow{2}{*}{$\begin{array}{c}\text { The Availability } \\
\text { of Posyandu }\end{array}$} & Available & 1 & 1 & 1 & 1 \\
\hline & Not Available & $1.01(0.94-1.10)$ & $1.05(0.96-1.15)$ & $1.14^{* *}(1.06-1.24)$ & $1.17^{* *}(1.07-1.27)$ \\
\hline \multirow{3}{*}{$\begin{array}{l}\text { Travel Time to } \\
\text { Posyandu }\end{array}$} & $\leq 15 \min$ & 1 & 1 & 1 & 1 \\
\hline & $>15 \min$ & $0.94(0.78-1.13)$ & $0.97(0.78-1.20)$ & $1.05(0.87-1.26)$ & $1.07(0.87-1.31)$ \\
\hline & Not Available & $1.01(0.94-1.09)$ & $1.05(0.96-1.15)$ & $1.15^{* *}(1.06-1.24)$ & $1.17^{* *}(1.08-1.28)$ \\
\hline \multirow{3}{*}{$\begin{array}{l}\text { Travel Cost to } \\
\text { Posyandu }\end{array}$} & $<5000$ Rupiah & 1 & 1 & 1 & 1 \\
\hline & $\geqslant 5000$ Rupiah & $1.18^{* *}(1.07-1.29)$ & $1.19 * *(1.07-1.32)$ & $1.32 * *(1.20-1.45)$ & $1.36^{* *}(1.23-1.51)$ \\
\hline & Not Available & $1.05(0.97-1.14)$ & $1.10 *(1.01-1.21)$ & $1.23^{* *}(1.13-1.33)$ & $1.27^{* *}(1.16-1.39)$ \\
\hline
\end{tabular}

Notes: $\mathrm{cOR}=$ Crude Odds Ratio; aOR $=$ Adjusted Odds Ratio; $\mathrm{CI}=$ Confidence Interval; ${ }^{+}$Healthy weight is the reference category; ${ }^{*} p<0.05 ; * * *<0.01{ }^{\text {a }}$ adjusted for breastfeeding, father's education, and parental BMI.

\section{Discussion}

Primary health care is practical, scientificially sound, socially acceptable health care made accessible and affordable at the country and community levels. The Alma-Ata Declaration, emphasises that primary health care should be accessible to all, and that it should involve everyone [7]. Using 
nationally representative population-based data concerning overweight and obesity in children in Indonesia, we pioneered an exploration of the associations of the availability of Posyandu, travel time to Posyandu, and travel cost to Posyandu with overweight and obesity in children of different household wealth levels. Our findings suggested that children who lived in areas without a Posyandu were more likely to be obese.

Having a Posyandu more than 15 min away, or having to spend more than 5000 Rupiah on travel was associated with a greater risk of obesity than having no Posyandu. The reason for this is likely related to accessibility issues. Even if mothers were aware a Posyandu was nearby, they did not always access the services, perhaps due to geographic barriers (e.g., travel constraints) and economic barriers (e.g., travel expenses). This situation can impede seeking care. The reluctancy of visiting a Posyandu can in turn raise the risk of obesity. The rich-poor gaps in health status and service access remain crucial issues in Indonesia [17]. Household wealth was found to be an effect modifier of the relation between the availability of Posyandu, travel time to Posyandu, travel cost to Posyandu and child weight status. Non-availability of Posyandu and higher travel costs ( $\geqslant 5000$ Rupiah) showed significant associations with the odds of being obese among wealthier families; longer travel time ( $>15$ min) showed no such association. Wealthier parents have good jobs and typically want to provide their children a "modern" lifestyle, providing plenty of modern recreational facilities, such as TVs and computers. These parents often give pocket money to their children, who then use the money to buy snacks. The results are a higher consumption high-calorie food and an avoidance of physically tough tasks. For these reasons, childhood overweight and obesity are more widespread in wealthier families [22]. According to our results, the risk of obesity in children of wealthier families living in communities without Posyandu was higher than that in children of poorer families. Some possible reasons are our limited sample size $(N=12,620)$ and factors characteristic in the poorer families, such as insufficient knowledge, inaccessible resources, and limited time. Overall, the prevalence of obesity in children was lower in the poorer.

In our study, we found that higher travel costs ( $\geqslant 5000$ Rupiah) showed a significant association with the odds of being obese among wealthier families. For poorer families, longer travel time showed a significant association with the odds of being obese. These association was not particularly strong, and these variables were unable to explain much of the observed differences between households of different wealth levels.

Previous studies [23-27] have reported that outcomes of clinical interventions for pediatric obesity in primary care settings are variable. Some interventions promote changes in diet, physical activity, or television viewing but do not achieve reductions in BMI [25,26]. Others have favorable, although small, effects on BMI $[23,24,27]$. MCH centers are often unfeasible because of barriers associated with accessibility, transportation, and cost [28,29].

Our study had a number of limitations. BMI as a measure of weight status, given its consistently high specificity and good correlations with more direct measures of adiposity compared to other antropometric measurements, is generally useful in pediatric practice [30,31]. However, BMI is likely to introduce misclassification problems and an estimation bias for the effects related to the relationship between the availability of Posyandu and child weight status. Another limitation is the likely existence of other unmeasured variables that contribute to child weight status, such as the provision of infant feeding advice relevant to obesity prevention including best practice formula feeding and parental feeding behaviors as well as promoting active play and limiting sedentary behavior. The impact of variables such as these deserves further research. The primary limitation of the cross-sectional study design is the lack of evidence of a temporal relationship between exposure and outcome. A longitudinal design would provide a better picture about the impact of the availability of Posyandu on childhood obesity. There were no problems reported in understanding what information was requested for travel time and cost to Posyandu. However some respondents, particularly those who used private cars or motorcycles as transportation, might have lacked knowledge or obtained unclear information about the exact travel time and costs. To account for expenses, these participants needed to consider 
the distance driven, fuel costs, and other running costs of the car. Some respondents likely lacked the information to perform such accounting. Public transportation is easier to account for due to clear ticket costs. Posyandu has been considered as the most essential services at the village level to enhance the nutrition improvement of maternal and child health [14]. Eventhough mothers are encouraged to take their young children (five-year-olds and below) to the Posyandu instead of other health facilities, it is also possible that some mothers took their children to another health facility for any reason and could have resulted in an underestimation of the association between the availability of Posyandu and obesity in children. Our study did not emphasize the variance or weights of subpopulations such as the Graubard and Korn in our complex sample design [32]. When some sampled PSUs have no observations in the subset of interest, these assumptions are violated. The strength of our study was the dataset using a rigorous sampling design to select a large sample of a representative group of children. The number of participants included in this study was larger than those of other studies. Moreover, our measurement methods employed by trained interviewers (usually nurses) for height and weight are more accurate than self-reported measurements. The current scientific research on childhood obesity prevention and treatment practices of Posyandu in Indonesia is insufficient. This study adds to the limited information of the existing studies on the Posyandu nutrition program in Indonesia.

\section{Conclusions}

Our results suggest that the availability of Posyandu has a protective association with childhood obesity in Indonesia. Household wealth modified this association. Promoting healthy weight gain fits well with the Posyandu role. Solutions to improving obesity prevention and treatment practices may include further developing Kader counseling and behavior change skills, such as reflective listening, motivational interviewing and goal setting to enable them in raising the issue of weight in a sensitive and nonjudgmental manner in obesity prevention advice with parents' roles in promoting optimal growth and development, specifically using delivery methods that overcome travel time and expense. The Kader should make continuous efforts to encourage the mothers to take their children to Posyandu regularly. With this additional support, Posyandu services are well placed to play an important role in obesity prevention and treatment in early life.

Acknowledgments: We are grateful to The National Institute of Health Research and Development (NIHRD), Ministry of Health Republic of Indonesia for providing us with the 2013 Riskesdas data. This project was partially supported by funding from a scholarship from the International Health Program of National Yang Ming University. The funder had no role in any aspect of the analysis, drafting, review, or approval of this manuscript.

Author Contributions: All authors contributed to the drafting, review, and approval of this manuscript. Helen Andriani conceived and designed the study, carried out the statistical analyses, and wrote the paper. Chu-Yung Liao analyzed the data and reviewing the draft. Hsien-Wen Kuo contributed to conception and design of the study, analyses and interpretation of data, draft review, as well as the final approval of the version to be published.

Conflicts of Interest: The authors declare no conflict of interest.

\section{References}

1. Popkin, B.M. The nutrition transition and obesity in the developing world. J. Nutr. 2001, 131, 871s-873s. [PubMed]

2. De Onis, M.; Blossner, M.; Borghi, E. Global prevalence and trends of overweight and obesity among preschool children. Am. J. Clin. Nutr. 2010, 92, 1257-1264. [CrossRef] [PubMed]

3. Kementerian Kesehatan. Result of 2007 Basic Health Research; Department of Health, Ministry of Health of Indonesia: Jakarta, Indonesia, 2007.

4. Kementerian Kesehatan. Result of 2010 Basic Health Research; Department of Health, Ministry of Health of Indonesia: Jakarta, Indonesia, 2010.

5. Pi-Sunyer, X. The medical risks of obesity. Postgrad. Med. 2009, 121, 21-33. [CrossRef] [PubMed]

6. Raj, M. Obesity and cardiovascular risk in children and adolescents. Indian J. Endocrinol. Metabol. 2012, 16, 13-19. [CrossRef] [PubMed] 
7. World Health Organization. Primary Health Care. Report of the International Conference on Primary Health Care; World Health Organization: Geneva, Switzerland, 1978.

8. Yoshihara, D. Indonesia Dalam Angka (Yearly); Depkes RI: Jakarta, Indonesia, 1998.

9. Hunter, C.L. Posyandu: Disjunctions between Policy and Practice in Lombok; Women in Asia Newsletter: Queensland, Australia, 1995.

10. Operational Working Group, Kementerian Kesehatan. Pedoman Umum Pengelolaan Posyandu; Ministry of Health of Indonesia: Jakarta, Indonesia, 2011; pp. 6-7.

11. Kurniawan, A. Policies in alleviating micronutrient deficiencies: Indonesia's experience. Asia Pac. J. Clin. Nutr. 2002, 11, S360-S370. [CrossRef]

12. Santoso, H.S.; Chauls, D.S. Community Participation in the Indonesian Family Planning Program: The Village Perspective and Management Strategies; Management Sciences for Health: Boston, MA, USA, 1992.

13. Wilopo, S.A.; Mosley, W.H. The Relationship of Child Survival Intervention Programs to the Practice of Contraception: A Case Study in Indonesia; Johns Hopkins Population Center, Johns Hopkins School of Public Health: Baltimore, MD, USA, 1993.

14. Goi-Unicef. Comprehensive Early Childhood Development and Early Learning in Support of Families and Communities in Poor and Rural Areas of Indonesia; GOI-UNICEF Cooperation Framework: Jakarta, Indonesia, 2007.

15. Anwar, F.; Khomsan, A.; Sukandar, D.; Riyadi, H.; Mudjajanto, E.S. High participation in the Posyandu nutrition program improved children nutritional status. Nutr. Res. Pract. 2010, 4, 208-214. [CrossRef] [PubMed]

16. Husaini, M.A.; Satoto, K.D. The Use of RAP in the Assessment of Growth Monitoring and Promotion in North Sulawesi: Indonesia. Avaliable online: http://www.popline.org/node/335652\#sthash.xcE2zT7E.dpuf (accessed on 2 March 2016).

17. Thabrany, H. Human Resources in Decentralized Health Systems in Indonesia: Challenges for Equity; Regional Health Forum: Jakarta, Indonesia, 2006; pp. 75-88.

18. Marmot, M. Social determinants of health inequalities. Lancet 2005, 365, 1099-1104. [CrossRef]

19. Whitehead, M. A typology of actions to tackle social inequalities in health. J. Epidemiol. Community Health 2007, 61, 473-478. [CrossRef] [PubMed]

20. Onis, M. Assessment of differences in linear growth among populations in the WHO Multicentre Growth Reference Study. Acta Paediat. 2006, 450, 56-65.

21. De Onis, M.; Onyango, A.W.; Borghi, E.; Siyam, A.; Nishida, C.; Siekmann, J. Development of a WHO growth reference for school-aged children and adolescents. Bull. WHO 2007, 85, 660-667. [CrossRef] [PubMed]

22. O'Dea, J.A.; Eriksen, M.P. Childhood Obesity Prevention: International Research, Controversies, and Interventions; Oxford University Press: Oxford, UK, 2010.

23. DeBar, L.L.; Stevens, V.J.; Perrin, N.; Wu, P.; Pearson, J.; Yarborough, B.J.; Dickerson, J.; Lynch, F. A primary care-based, multicomponent lifestyle intervention for overweight adolescent females. Pediatrics 2012, 129, e611-e620. [CrossRef] [PubMed]

24. Dolinsky, D.H.; Armstrong, S.C.; Walter, E.B.; Kemper, A.R. The effectiveness of a primary care-based pediatric obesity program. Clin. Pediat. 2012, 51, 345-353. [CrossRef] [PubMed]

25. McCallum, Z.; Wake, M.; Gerner, B.; Baur, L.A.; Gibbons, K.; Gold, L.; Gunn, J.; Harris, C.; Naughton, G.; Riess, C.; et al. Outcome data from the LEAP (Live, Eat and Play) trial: A randomized controlled trial of a primary care intervention for childhood overweight/mild obesity. Int. J. Obes. 2007, 31, 630-636. [CrossRef] [PubMed]

26. Taveras, E.M.; Gortmaker, S.L.; Hohman, K.H.; Horan, C.M.; Kleinman, K.P.; Mitchell, K.; Price, S.; Prosser, L.A.; Rifas-Shiman, S.L.; Gillman, M.W. Randomized controlled trial to improve primary care to prevent and manage childhood obesity: The high five for kids study. Arch. Pediat. Adolesc. Med. 2011, 165, 714-722. [CrossRef] [PubMed]

27. Wald, E.R.; Moyer, S.C.; Eickhoff, J.; Ewing, L.J. Treating childhood obesity in primary care. Clin. Pediat. 2011, 50, 1010-1017. [CrossRef] [PubMed]

28. Ambler, K.A.; Hagedorn, D.W.; Ball, G.D. Referrals for pediatric weight management: The importance of proximity. BMC Health Serv. Res. 2010, 10, 302. [CrossRef] [PubMed]

29. Hampl, S.; Paves, H.; Laubscher, K.; Eneli, I. Patient engagement and attrition in pediatric obesity clinics and programs: Results and recommendations. Pediatrics 2011, 128, S59-S64. [CrossRef] [PubMed] 
30. Reilly, J.J. Diagnostic accuracy of the BMI for age in paediatrics. Int. J. Obes. 2006, 30, 595-597. [CrossRef] [PubMed]

31. Whitlock, E.P.; Williams, S.B.; Gold, R.; Smith, P.R.; Shipman, S.A. Screening and interventions for childhood overweight: A summary of evidence for the U.S. Preventive Services Task Force. Pediatrics 2005, 116, e125-e144. [CrossRef] [PubMed]

32. Graubard, B.I.; Korn, E.L. Survey inference for subpopulations. Am. J. Epidemiol. 1996, 144, $102-106$. [CrossRef] [PubMed]

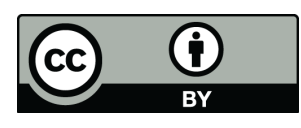

(c) 2016 by the authors; licensee MDPI, Basel, Switzerland. This article is an open access article distributed under the terms and conditions of the Creative Commons by Attribution (CC-BY) license (http://creativecommons.org/licenses/by/4.0/). 